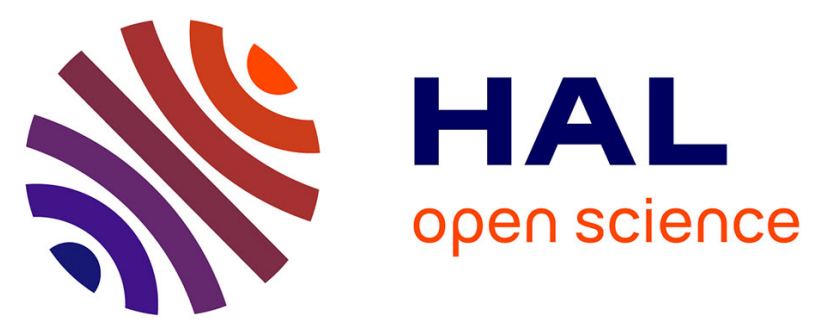

\title{
Floodplain water storage in the Negro River basin estimated from microwave remote sensing of inundation area and water levels
}

Frédéric Frappart, F. Seyler, Jean-Michel Martinez, Juan Gabriel Leon, A. Cazenave

\section{To cite this version:}

Frédéric Frappart, F. Seyler, Jean-Michel Martinez, Juan Gabriel Leon, A. Cazenave. Floodplain water storage in the Negro River basin estimated from microwave remote sensing of inundation area and water levels. Remote Sensing of Environment, 2005, 99 (4), pp.387-399. 10.1016/j.rse.2005.08.016 . ird-00385169

\section{HAL Id: ird-00385169 \\ https://hal.ird.fr/ird-00385169}

Submitted on 10 Jun 2009

HAL is a multi-disciplinary open access archive for the deposit and dissemination of scientific research documents, whether they are published or not. The documents may come from teaching and research institutions in France or abroad, or from public or private research centers.
L'archive ouverte pluridisciplinaire HAL, est destinée au dépôt et à la diffusion de documents scientifiques de niveau recherche, publiés ou non, émanant des établissements d'enseignement et de recherche français ou étrangers, des laboratoires publics ou privés. 


\section{Editorial Manager(tm) for Remote Sensing of Environment Manuscript Draft}

Manuscript Number: RSE-D-05-00120R1

Title: Floodplain Water Storage in the Negro River Basin Estimated from Microwave Remote Sensing of Inundation Area and Water Levels

Article Type: Full length article

Section/Category:

Keywords: remote sensing; hydrology; altimetry; water Level; water volume variation.

Corresponding Author: Mr. Frédéric Frappart,

Corresponding Author's Institution: LEGOS-GRGS/CNES

First Author: Frédéric Frappart

Order of Authors: Frédéric Frappart; Frédérique Seyler, Dr.; Jean-Michel Martinez, Dr.; Juan G. León; Anny Cazenave, Dr.

Manuscript Region of Origin: 
Abstract : The objective of this study is to determine spatio-temporal variations of water volume over inundated areas located in large river basins using combined observations from the Synthetic Aperture Radar (SAR) onboard the Japanese Earth Resources Satellite (JERS1), the Topex/Poseidon (T/P) altimetry satellite, and in-situ hydrographic stations. Ultimately, the goal is to quantify the role of floodplains for partitioning water and sediment fluxes over the great fluvial basins of the world. SAR images are used to identify the type of surface (open water, inundated areas, forest) and, hence, the areas covered with water. Both radar altimetry data and in-situ hydrographic measurements yield water level time series. The basin of the Negro river, the tributary which carries the largest discharge to the Amazon river, was selected as a test site. By combining area estimates derived from radar images classification with changes in water level, variations of water volume (focusing on a seasonal cycle) have been obtained. The absence of relationship between water volume and inundated area, reflecting the diverse and widely dispersed floodplains of the basin, is one of the main result of this study. 


\section{Floodplain Water Storage in the Negro River Basin Estimated from Microwave Remote Sensing of Inundation Area and Water Levels}

Frédéric Frappart ${ }^{(1)}$, Frédérique Seyler ${ }^{(2)}$, Jean-Michel Martinez ${ }^{(3)}$, Juan G. León ${ }^{(2)}$ and Anny Cazenave ${ }^{(1)}$.

(1) Laboratoire d'Etudes en Géophysique et Océanographie Spatiale, Centre National d'Etudes Spatiale, 18 Av. Edouard Belin 31401 Toulouse Cedex 9, France. (phone :0033-5-61332930;fax :0033-5-61253205 ; email : frappart@notos.cst.cnes.fr)

(2) Laboratoire des Mécanismes et Transferts en Géologie, IRD, Observatoire MidiPyrénées, 14, Av. Edouard Belin, 31400 Toulouse, France.

(3) Laboratoire des Mécanismes et Transferts en Géologie, IRD, Maison de la Télédétection, 500, rue J-F Breton, 34093 Montpellier Cedex 5, France

Keywords : Remote sensing, Hydrology, Altimetry, Water Level and Water Volume Variation

Abstract : The objective of this study is to determine spatio-temporal variations of water volume over inundated areas located in large river basins using combined observations from the Synthetic Aperture Radar (SAR) onboard the Japanese Earth Resources Satellite (JERS-1), the Topex/Poseidon (T/P) altimetry satellite, and in-situ hydrographic stations. Ultimately, the goal is to quantify the role of floodplains for partitioning water and sediment fluxes over the great fluvial basins of the world. SAR 
images are used to identify the type of surface (open water, inundated areas, forest) and, hence, the areas covered with water. Both radar altimetry data and in-situ hydrographic measurements yield water level time series. The basin of the Negro river, the tributary which carries the largest discharge to the Amazon river, was selected as a test site. By combining area estimates derived from radar images classification with changes in water level, variations of water volume (focusing on a seasonal cycle) have been obtained. The absence of relationship between water volume and inundated area, reflecting the diverse and widely dispersed floodplains of the basin, is one of the main result of this study.

\section{INTRODUCTION}

Extensive floodplains along large South American rivers, such as Amazon, Paraná or Orinoco, have a significant role in the hydrological cycle of fluvial basins. Transport of water and sediments by rivers is substantially modified during residence of river water in floodplains. During its stay in these inundation areas, river water from is not only delayed in its transit to sea and affected by evapotranspiration, but it is also often subject to large biogeochemical changes due to sedimentation, nutrient uptake by the biota, and modifications of redox conditions (Hamilton et al., 2002). The water storage in these wetlands and its outflow represent a significant part of the water balance in the basin (Alsdorf et al., 2001; Richey et al., 1989) .

Determining the temporal variation of water volume stored in the floodplains of great river basins is the subject of many applications in hydrology. For the inundated areas permanently or temporarily connected to main channels, the determination of the water volume variation is equivalent to the estimation of water volume potentially stored and/or released by the valley reach during flood stages. The water volume variation in this type of inundated areas is an 
important parameter for the hydrodynamic modeling of the river flow and the determination of its transport capacity. For the inundated areas that never connect to the main channel, the volume variation is essentially a function of the base flow variation, the inputs from the local basin and the rain. Some floodplains present both types of flooding zones. Areas where the river water mixes with the local water are called "perirheic zones" (Mertes, 1997). In all cases, the inundation area is a buffer zone between the river and the upland watershed. The water volume variation represents the flood pulse of floodplains as expressed by Junk et al. (1989). Therefore, it is a key ecological characteristic that cannot be easily measured in the field.

To better understand the hydrology of large river systems, information about the dynamics of inundation patterns (extent of flooded areas) and water levels of main river channels, tributaries and associated floodplains is required (Alsdorf et al., 2000). Spatial and temporal patterns of inundation areas can be inferred from multi-temporal satellite images: visible/infrared (IR) or SAR sensors are used to delineate floodplains (Mertes et al., 1995 ; Smith, 1997 ; Töyrä et al., 2001 ; Hess et al., 2004). In addition, the potential of satellite radar altimetry for monitoring water levels of large rivers has already been demonstrated (Birkett, 1998 ; Oliveira Campos et al., 2001 ; Maheu et al., 2003). Birkett et al. (2002) undertook an extensive validation study of water levels derived from Topex/Poseidon radar over the entire Amazon basin and used satellite radar altimetry to estimate elevation profiles and water surface gradients along the Amazon mainstream.

In this study, a new method is proposed to estimate both flooded area and water levels to determine the water volume stored in the floodplains of the Negro river, the largest tributary of the Amazon river, during the 1995-1996 seasonal cycle.

\section{PREVIOUS STUDIES}


Many methods have been employed to estimate the extent of inundation and a review of how remote sensing is used to map inundation can be found in Smith (1997). The simplest model used to determine the extent of flood consists in intersecting a plane representing the water surface with a Digital Elevation Model (DEM) (Priestnall et al., 2000). However, it leads to an overestimation of the flooding zones with some areas that are not connected to the flood being incorrectly considered as inundated (Bates, 2000). Inundation patterns of large floodplains of South America have been derived using the polarization difference at $37 \mathrm{GHz}$ of the SMMR passive microwave emission measurements (Hamilton et al., 2002). The spatial resolution of the grids derived from SMMR data is $0.25^{\circ}$. Approximate boundaries of floodplains can thus be retrieved. Relations between stage and flooded area have been derived using records from in-situ gauge-stations (Sippel et al., 1998). These studies estimated the spatial and temporal variability of floodplain inundation. Richards et al. (1987) reported the bright return of flooded forest in L band by corner reflection between trunks and water surface beneath the canopy. Early results from Hess et al. (1995) deal with the mapping of inundated areas of the central Amazon floodplain with the SIR-C SAR, and Wang et al. (1995) compared C- and L-bands with respect to the detection of flooding in Amazonian forests. Smith et al. (1995, 1996) estimated discharge from braided glacial rivers with ERS-1 SAR images. Almost all studies dealing with the extent of inundation in the Amazon floodplain been with the central main stem of the Amazon except for Richey et al. (2002), who used the Amazon basin wide inundation map based on the dual-season JERS-1 mosaic from (Hess et al., 2003) to estimate outgassing from Amazonian rivers and wetlands.

To estimate the flood stage, various remote sensing methods have been tested because in-situ gauges are very seldomly located in wetlands. Inundation areas and ground measurements of stage yield a high linear correlation, for example in the case of the Ob river (Usachev, 1983), and therefore, water elevation has been estimated using the inundation extent. Hayashi and 
van der Kamp (2000) proposed a power function with two parameters to represent the relation of elevation with area or volume in small shallow ponds or topographic depression of the Northern American prairie regions. Townshend and Walsh (1998) examined various procedures to determine the elevation of the flood level from a detailed DEM. Generally, the modeling of flooding processes is achieved through 2-D formulations, but stage data are lacking for constraining and validating these models. Townsend and Foster (2002) proposed a SAR-based statistical model to predict flood extent and river discharge in a North-American river basin. Landsat Thematic Mapper imagery has also been used to understand the relationship between wetland inundation and river flow (Frazier et al., 2003). Stage estimation by satellite radar altimetry coupled with flooded area estimation by SAR imagery offers an alternative approach that has not been utilized in previous studies.

\section{THE NEGRO RIVER SUB-BASIN}

The Negro River sub-basin covers only $12 \%$ of the entire Amazon basin. However, it is the largest tributary to the Amazon river and ranks as the fifth largest river in the world for its water discharge (Meade et al., 1991). It is the major northern tributary as it joins the Solimões River to form the Amazon downstream from Manaus, and drains about 700,000 km² of Colombia (10\%), Venezuela (6\%), Guyana (2\%) and Brazil (82\%). It extends from $73.25^{\circ}$ to $59.35^{\circ}$ longitude West and from $5.4^{\circ}$ North to $3.35^{\circ}$ latitude South (Fig. 1). It is characterized by the dark color of its water, due to high content in dissolved organic matter and a low sediment load (Sternberg, 1975), and is a low gradient river, which partly accounts for (with the high amount of precipitation) the considerable extension of the floodplains. Rainfall in the sub-basin varies greatly both in space and time. Mean annual precipitation rates vary by more than $50 \%$ within the Negro river basin, from less than $2000 \mathrm{~mm} / \mathrm{yr}$ (with 
minimum values less than $1700 \mathrm{~mm} / \mathrm{yr}$ recorded in the northern part of the Branco river basin), to between 2250 and $2500 \mathrm{~mm} / \mathrm{yr}$ near Manaus and up to $3000 \mathrm{~mm} / \mathrm{yr}$ in the northwest (Liebmann and Marengo, 2001). Timing of the rainy season differs widely along a south to north gradient: the beginning of the rainy season occurs in December in the south and in March or April in the north, whereas the rainy period ends from May to October (Marengo et al., 2001).

\section{DATASETS AND METHODS}

\subsection{DATASETS FOR FLOOD MAPPING}

\subsubsection{JERS-1 RADAR MOSAICS}

High resolution maps (100 m resolution) of the entire rain forests across the tropical regions were acquired in the framework of the Global Rain Forest Mapping Project (GRFM), an international collaboration initiated and managed by the National Space Development Agency of Japan (NASDA). JERS-1 was an L-band (wavelength of $23.5 \mathrm{~cm}$ ) SAR satellite (Chapman et al., 2002), launched in February 1992 and operated until October 1998. The L-band signals are sensitive both to open water and standing water below the forest canopy (Rosenqvist et al., 2000). The GRFM project consisted of dual-season mapping of the global tropical forests during less than a one year period. The data acquired over the Amazon basin were composed of a set of two continental-scale mosaics acquired in relatively short time spans : September to December 1995 and May to July 1996. They were made available by the GRFM project on CD-ROMs where the continental-scale mosaics were divided into smaller regional mosaics (typically $6^{\circ} \times 6^{\circ}$ ). These two mosaics captured low and high water stages for the major part of the Amazon basin. Although these two mosaics are not an exact match for the high and low stages in the case of the Negro river sub-basin, they will be nonetheless thus defined in the following sections. The hydrological cycle as revealed by $\mathrm{T} / \mathrm{P}$ data will be discussed and we 
will estimate the difference relative to ground measurements of high and low stages within the basin.

\subsubsection{CLASSIFICATION METHOD FOR FLOOD EXTENT}

Several studies have reported the classification of the GRFM dual mosaics over Brazil to discriminate main land cover types and map either the extent of deforestation or delineate the flooded areas (Saatchi et al., 2000; Siqueira et al., 2003; Hess et al., 2003). Classification approaches have been restricted to a simple but nonetheless robust classifier based on the thresholding of each individual mosaics in order to retrieve pre-defined classes. The two individual backscatter vectors have been replaced by two composite vectors based on (i) the mean backscatter coefficient computed over the two seasons and (ii) the ratio of both seasons giving the change value. Mean backscatter provides the rough vegetation type while the change channel yields the estimate regarding the probability of change. As the data provided is absolutely calibrated and little sensitive to any other effect than flood (i.e., vegetation growth, soil moisture), any significant change is linked to a variation of the flood status.

The classifier allocates a status to the pixel in relation to the flood : never flooded; occasionally flooded; permanently flooded. Also provided is the broad land cover type : open water / bare soil / pasture / low vegetation / forest. This leads to an 8-theme classification (Fig. 2) excluding a number of combinations between flood status and land cover type (for instance open water and non-flooded): (1) open water / (2) occasionally flooded forest / (3) non flooded forest / (4) non flooded bare soils or low vegetation / (5) occasionally flooded pastures / (6) occasionaly flooded low vegetation / (7) always flooded forest / (8) submerged vegetation. Methodological artifacts caused by the relief, urban areas or rivers of limited width were identified and corrected.

Validation against alternative dataset from other remote sensing data source is impossible at a large scale since only radar data are sensitive to flood conditions whatever the vegetation 
cover. Unfortunately, no other radar cover of the Amazon basin exists for the area with roughly the same specifications (wavelength, spatial resolution). The best that can be done is local-scale validation and extrapolation to the rest of the dataset. This approach has been already developed using either airborne radar data, airborne digital videography or direct fieldwork on limited areas. The estimation of accuracy for a test site near Obidos confirmed the other fieldwork validations, with a conservative classification accuracy better than $90 \%$ for forested areas and $70 \%$ for low vegetated themes due to the low sensitivity of the L-band data to the low vegetation and smooth surfaces.

Classification of the JERS-1 dual mosaics allows us to map the flooded areas for low water stage (i.e., permanently flooded areas) and high water stage (combination of permanently and temporarily flooded areas) during the 1995-1996 seasonal cycle. The situation corresponding to JERS-1 low water stage (Fig. 3) derived from the combination of classes (1) and (6) whereas the JERS-1 high water stage (Fig. 4) is obtained from the combination of classes (1), (2), (5), (6), (7) and (8).

\subsection{TOPEX/POSEIDON DATASET FOR WATER STAGES}

\subsubsection{TOPEX/POSEIDON RAW-ALTIMETER MEASUREMENTS}

The T/P radar altimeter is the first dual frequency sensor of a joint French and U.S. mission, whose goal is to substantially improve our understanding of global ocean dynamics by making accurate measurements of the ocean surface topography (Fu and Cazenave, 2001). It operates in $\mathrm{Ku}$ and C-band, at frequencies (wavelengths) of $13.6 \mathrm{GHz}(2.3 \mathrm{~cm})$ and $5.3 \mathrm{GHz}$ $(5.8 \mathrm{~cm})$, respectively. During its 10 -day repeat cycle, T/P has provided along-track nadir measurements of Earth surface elevation (ocean and continental surfaces) between $66^{\circ}$ latitude north and $66^{\circ}$ latitude south since it was launched in October 1992. Radar altimetry entails vertical range measurements between the satellite and the Earth surface. The water 
levels to the reference ellipsoid are given by the difference between the satellite orbit information and the range (Fu and Cazenave, 2001) or altimetric height.

Measurements and associated corrections (regularly updated and upgraded) are contained in the Geophysical Data Records (GDR) made available by the Archiving, Validation and Interpretation of Satellite Data in Oceanography (AVISO) data centre at the Centre National d'Etudes Spatiales (CNES), (AVISO, 1996). Data consist of range values derived from radar altimeter echoes at $1 / 10 \mathrm{~s}($ or $10 \mathrm{~Hz}$ ) and averaged values at $1 \mathrm{~s}$ (or $1 \mathrm{~Hz}$ ), corresponding to along-track ground spacing of $596 \mathrm{~m}$ and $5.96 \mathrm{~km}$, respectively. The corrections applied in this study are ionospheric, dry tropospheric, solid Earth tide, and Pole tide corrections. From the two ionospheric corrections available, we applied the onboard Doppler Orbitography and Radiopositioning Integrated by Satellite (DORIS) based on the measurement of the ionosphere electronic content (the dual-frequency ionospheric correction, generally used in ocean studies, is not valid over land). The wet tropospheric correction is not applied in the present study. From the two tropospheric corrections available, the first one, derived from the Topex Microwave Radiometer (TMR) measurements of water vapour, is unusable over land due to microwave emissions from continental surfaces. The second one, derived from estimates of atmospheric water vapour content by the General Circulation Model (GCM) from the European Centre for Medium Range Weather Forecast (ECMWF), is lacking in the AVISO database. The lack of the wet tropospheric correction can lead to an overestimation of the altimetric range up to $30 \mathrm{~cm}$. The spatial and temporal variations of the wet tropospheric correction are assumed to be negligible within the Negro river sub-basin (equatorial location and relatively small spatial extent). The location of the satellite tracks over Negro River basin is given in Fig. 1.

\subsubsection{T/P TIME SERIES CONSTRUCTION}


Each intersection between the river or flooded areas (as determined by the SAR classification) and the satellite ground-track defines a so-called "altimetric station", practically defined as a rectangular window. In each cycle, the water level at a given altimetric station is obtained by the computation of the median of all the high-rate data $(10 \mathrm{~Hz})$ included in the rectangular window. This process, repeated every 10 days, allows the construction of the time series of water level associated with each altimetric station. The dispersion in L1 norm is given by the estimator known as median absolute deviation (Eq. 1):

$$
M A D(x)=\frac{1}{N-1} \sum_{i=1}^{N}\left|x_{i}-x_{\text {med }}\right|
$$

where $\operatorname{MAD}(\mathrm{x})$ is the mean absolute deviation of the observations, $\mathrm{N}$ the number of observations, $\mathrm{x}_{\mathrm{i}}$ the $\mathrm{i}^{\text {th }}$ observation, and $\mathrm{x}_{\mathrm{med}}$ the median of the observations.

Water levels are expressed with reference to geoid EIGEN-GRACE02S. This geoid is derived from the first year of GRACE space gravity mission measurements, which monitored the time-space variations of the gravity field with a resolution of $2^{\circ} \times 2^{\circ}$ at the equator and an accuracy of $1 \mathrm{~cm}$ on the geoid height (Reigber et al., 2005).

Examples of water level time series are given for different types of water (Fig. 5):

- single channel river,

- complex channel rivers : in this case, an altimeter virtual station corresponds to each channel,

- flooded areas.

Fig. 5 shows a comparison between an altimetric time series located $8.5 \mathrm{~km}$ uspstream Manaus and the in-situ recorded water levels at Manaus gauging station. In this example, the accuracy of the T/P derived time-series is $27 \mathrm{~cm}$.

The width of the rectangular window that defines the altimetric station depends on the size of the flooded zone, but is generally about $0.05^{\circ}$. When the dimension of the flooded area, as is 
often the case, exceeds $0.05^{\circ}$, several altimetric stations are defined. Increasing the number of altimetric stations improves the sample size and leads to a better estimation of water level variations at fine scales.

\subsubsection{IN-SITU TIME SERIES CONSTRUCTION}

The Brazilian Water Agency (Agencia Nacional de Aguas or ANA) is in charge of managing a network of 571 gauging stations in the Brazilian part of the Amazon basin (http://www.ana.gov.br). At each station, daily measurements of water stage are collected and daily estimates of discharge are produced using rating curves, obtained from periodic (sometimes several times a year) simultaneous measures of stage and discharge. Among these 571 inventoried gauges, 46 are located in the Negro River sub-basin and 25 of them have records over the last 20 years (see their locations on Fig. 1). The others have only temporary records that did not include the 1995-1996. From these 25 in-situ gauge stations, only 8 are located within the T/P groundtracks framework and can, therefore be utilized, by interpolation of the river slope between the two nearest $\mathrm{T} / \mathrm{P}$ tracks, to estimate stage variation at the altimetric stations.

\subsection{WATER LEVEL MAPS FOR HIGH AND LOW STAGES}

Water level time series were available for $88 \mathrm{~T} / \mathrm{P}$ altimetric stations (Fig. 1). In addition, water level measurements from eight in-situ leveled gauge stations are used to complete the dataset. Values for minimum and maximum water levels were estimated at the date of the JERS mosaic. For each altimetric station, the value of the T/P time series, built from 10 days repeat cycle, was estimated by interpolation at the date of the JERS acquisition (the date of acquistion of the individual scenes composing the JERS mosaic can be found at http://trfic.jpl.nasa.gov/GRFM/jersframe.html). Water level maps for low and high water stage in the flooded zones were produced by linear interpolation using the eight nearest 
neighbours scheme to estimate the water level for each grid point. A grid step of $0.002^{\circ}$ was chosen, which represents about $200 \mathrm{~m}$, as we have not been able to retrieve valid altimeter data for rivers under $250 \mathrm{~m}$ width. The T/P intertrack is $315 \mathrm{~km}$ long at the equator. The upstream part of the Negro river is orientated North/South. It flows from West to East after the confluence with the Uaupes, a West/East flowing tributary. The Branco river is orientated North/South. Two types of intersection are observed: the satellite crosses the river and the satellite track runs along strike the river. Over the western/eastern flowing parts of the river network, the T/P tracks cross the river and its floodplain system, allowing to define several altimetric stations over the the river mainstream and the associated floodplains. As a consequence, the interpolation in the along-track direction follows the difference of water levels between the mainstream and the floodplain. In the cross-track direction, interpolation over several hundreds of kilometers will only reflect the mean slope of the river. Over the northern/southern flowing parts of the river network, the T/P tracks run along strike the river.. In these cases, depending on the choice of the geographical coordinates of the altimetric station, the time series can be influenced by the variation of level within the adjacent floodplain (Birkett et al., 2002). These authors did not report obvious amplitude or phase differences due to the inclusion of some floodplain. The difference of water levels between the mainstream and the inundated floodplain reported by Alsdorf (2003) on the Amazon floodplain $(\sim 11 \mathrm{~cm})$ is generally lower than the measurement dispersion. The water level maps for low and high stages obtained with this method are shown in Fig. 6 and Fig. 7, respectively, and from them estimated the difference between JERS-1 high and low stages (Fig. 8). A negligible number of values $(0.02 \%)$ were negative (mainly located on the boundaries where $-\mathrm{T} / \mathrm{P}$ or in-situ - are scarce or lacking). The strong seasonal water level variations of the lower Negro river can be recognized in the difference of water level of about $10 \mathrm{~m}$ near Manaus. However, these maps correspond to minimum and maximum water levels 
at the date of the JERS mosaics. As we have noted previously, they fail to match the effective high and low stages. Thus, the minimum and maximum stages from the T/P time series have been estimated.

\subsection{WATER VOLUME VARIATION ESTIMATION}

The combination of SAR images, radar altimetry measurements, and in-situ gauge stations, yields information on the water volume variation during the seasonal cycle. The Negro river was subdivided into eleven sub-basins corresponding to the major tributaries of the Negro river. For each sub-basin, the 2-D grid representing the water level variation was converted into an Arcview 3D format (Triangulated Irregulated Network or TIN) with a vertical step of $10 \mathrm{~cm}$ - the maximum accuracy that can be obtained from radar altimetry on rivers and wetlands (Birkett, 1998). 3D representations of the water stored during the 1995-1996 seasonal cycle were created, allowing us to compute the water volume variation between JERS-1 high and low stages. The error on the method was estimated using (Eq. 6):

$$
d \delta V=\sum_{i=1}^{n}\left(d S_{i} \delta h_{i}+S_{i} d \delta h_{i}\right) \quad(\text { Eq. 6) }
$$

where: $d \delta \mathrm{V}$ is the error on the water volume variation $(\delta \mathrm{V})$,

$\mathrm{S}_{\mathrm{i}}$ is the $\mathrm{i}^{\text {th }}$ elementary surface,

$\delta \mathrm{h}_{\mathrm{i}}$ is the $\mathrm{i}^{\text {th }}$ elementary water level variation between high and low stage,

$\mathrm{dS}_{\mathrm{i}}$ is the error on the $\mathrm{i}^{\text {th }}$ elementary surface,

$\mathrm{d} \delta \mathrm{h}_{\mathrm{i}}$ is the error on the $\mathrm{i}^{\text {th }}$ elementary water level variation between high and low stage.

The error sources include mis-classifications, T/P altimetry measurements and the linear interpolation method.

\subsection{ESTIMATION OF HALF-PEAK FLOW INTEGRATED DISCHARGE}


The half-flood peak time-integrated discharge represents the volume of water that has flown into the mainstream during the rising water period. It is defined as the ratio of the water potential storage within the floodplain over the effective volume of water that have flowing into the mainstream during the same period. The water potential storage is the result of our method of estimation of water volume variation. The effective water volume flowing into the main stream is the time-integrated discharge between low stage of 1995 and the peak flow of 1996 from each sub-basin. The discharge values used in this study are derived from water levels recorded at in-situ stations located at the mouth of each sub-basin.

\section{RESULTS AND DISCUSSION}

\subsection{SPATIAL DISTRIBUTION OF THE INUNDATED AREAS}

The results obtained by the JERS dual mosaic for the Rio Negro basin are given in Fig. 2. The total area subject to flooding is $35,944 \mathrm{~km}^{2}$ for the JERS- 1 low water acquisition and 152,721 $\mathrm{km}^{2}$ for the JERS-1 high water acquisition. Table 1 partitions flooded areas according to the type of surface and vegetation. The results of flood mapping are shown in Fig. 3 for JERS-1 low and high water stage. The two maps highlight the importance of floodplains in the Negro River sub-basin.

The different classes identified as inundated areas (permanent or temporary) by the classifier are not evenly distributed within the Negro River basin. This heterogeneous distribution causes the great variety of situations observed during the high and low water stages (Table 2 and Table 3). Generally, the inundated area is much wider (several times) during high water stage than low water stage, except for the Carabinani sub-basin in which $20 \%$ of the surface is always flooded. Different behaviours can be observed according to the geographical location of the sub-basins. In the eastern part of the basin (Negro upstream and Uaupes rivers), i.e., Cucui, Curicuriari, Sao Felipe and Serrinha sub-basins, almost 5\% of the basin is inundated during low water stage and 2 to 3 times more during high water stage. The situation 
is totally different in the northern part (Caracarai) and downstream (Foz do Branco, Unini, Jau, Negro downstream) : the flooded area during high water stage is between 15 and $30 \%$ (increase factor greater than 4). With $12 \%$ and $54 \%$ of the land being inundated during the low and high water stages respectively, the Branco river sub-basin differs from other downstream sub-basins in terms of importance of inundated areas. Its flow is controlled by the Negro River mainstem. As a consequence, a high percentage of the sub-basin is always inundated (up to $24 \%$ of the flooded areas of the Negro River basin during high water stage).

\subsection{HIGH AND LOW WATER LEVELS}

The T/P altimetry stations are unevenly distributed across the basin (Fig. 1). Among the 88 $\mathrm{T} / \mathrm{P}$ stations where water level time series can be built, 34 are located on rivers and 54 on wetlands. Five (four on the rivers and one on a flooded area) are located on the Uaupes river flowing from the Colombian part of the watershed, on the western side of the Negro basin. This part of the basin is poorly known, no records from in-situ gauges are available. Fifteen are located on the upper Negro, near the Venezuelan border and the divide with Orinoco basin. Most of them are present on a large unmonitored inundated area. Two in-situ gauges within this area have recorded data for the 1995-1996 period and can be levelled using altimetry. The presence of a great number of gauge stations (in-situ and altimetric) gives the opportunity to describe the hydrological cycle of that part of the basin. Some altimetric stations are located on the right bank of Negro River, in an unmonitored part of the basin. The others allow monitoring of the Branco River flowing from the north, and downstream along the Negro River. This important number of stations (96 encompassing 88 altimetric and 8 in-situ), distributed on river channels and wetlands, is necessary to estimate accurately water volume variations. Table 4 reports mean standard deviations for water levels on river channels and flooded areas. The precision is better on river channels than on inundated areas. 
Minimum standard deviations of around $10 \mathrm{~cm}$ are measured on downstream rivers with large open water areas when the pulse emitted by the altimeter is not scattered by vegetation, whereas maximum standard deviations of around $60 \mathrm{~cm}$ is observed on flooded areas covered with dense vegetation. In Table 4 are also reported the differences between water level measured at the dates of the JERS mosaic, and the minimum and maximum water levels, respectively measured at low and high stage (1995-1996) and for the whole period between 1992 and 2002. The difference is lower for inundated areas than for river channels, and is lower at low stage than high stage. The difference is about $0.4 \mathrm{~m}$ for low water stage and lower than $1 \mathrm{~m}$ for high water stage for the 1995-1996 period.

Using the altimetric gauge stations present on river channels, we have determined the profiles of Negro River and its main tributaries - Branco and Uaupes (Fig. 8). For each altimetric station, the difference between water levels recorded at the JERS mosaic date, and respectively the minimum level of 1995 and the maximum level of 1996 is reported in Table 5. For Uaupes River, low stage mean difference is about $1 \mathrm{~m}$, ranging from about $0.5 \mathrm{~m}$ upstream and reaching $2 \mathrm{~m}$ downstream, whereas for the high stage, the difference is quasiconstant around $1 \mathrm{~m}$. On the Branco River the differences are quasi-constant for high and low stage, respectively around $1 \mathrm{~m}$ and $0.30 \mathrm{~m}$. More important differences are observed on the Negro River mainstem : for low stage differences are lower than $1 \mathrm{~m}$, whereas they can reach several meters during high water stage. The JERS radar mosaic represents the low water stage for the downstream (southeastern part of the basin) but is out of phase with the lowest water levels for the northwestern part of the basin, whereas it is the contrary for the high water stage (representative for the northeastern part and not for the southeastern part). These underestimations of the maximum water level can lead to erroneous water volume estimation.

\subsection{WATER VOLUME VARIATIONS}


The water volume variations characterize the volume of water potentially stored in the inundated areas. The water volume variations are more important at the confluences between the mainstream and its tributaries (Serrinha, Foz do Branco, Branco and Negro downstream sub-basins). During high stage, the water level of the tributaries (Uaupes, Branco and Negro as a tributary of the Solimões) is controlled by the water level of the mainstem, causing large inundation near the confluences (Fig. 9). The intensity of this phenomenon is lower during low stage. These backwater effects have been already reported by Meade et al. (1991) in the entire Amazon basin and particularly in the Negro river sub-basin. We have then compared the water volume variations with the volume flowing during the flood from each sub-basin where discharge data were available. The percentage area of the basin that is inundated at high water stage is inversely related to the ratio between the flown water volume and the stored water volume, i.e. the storage capacity of the floodplains is related to their extent. But this relation is not proportional, and the storage capacity of the floodplains cannot be inferred from their spatial extent (Fig. 9 and Table 2). The nonlinear relationship between potential storage capacity within the floodplain and flown water volume during the flood is somewhat related to the residence time of the water in the floodplain. This ratio can be considered as a global indicator of the basin behaviour during flooding processes.

Using Eq. 6 and taking into account the different sources of error, we have estimated the minimum and maximum storage. For the whole basin, we obtained a minimum change in water storage $26 \%$ lower than our estimation and a maximum change $34 \%$ greater.

\section{CONCLUSION}

For the first time, the combined use of altimetric water level observations and inundation patterns to determine water volume variations provides valuable information on the inundation dynamics of river floodplains. In this study, we calculated the water storage changes during the 1995-1996 hydrological cycle of the Negro river. It corresponds to a 
volume variation of $331 \mathrm{~km}^{3}$ for the whole floodplain. This result was compared with the water volume flown during the flood. The storage capacity of the floodplain cannot be derived from their extent. The potential storage capacity within the floodplain is not proportional to the flown water during the flood.

The use of the GRFM dual-season mosaics of JERS-1 SAR images allows to accurately map (with a resolution of $100 \mathrm{~m}$ ) the Negro River basin according to the type of vegetation and the inundation status. The classification results were used to delineate flood extent at high and low stage. Unfortunately, the date of acquisition of the mosaics may not coincide with the real maxima (respectively minima) registered during the hydrological cycle. Characterization of the seasonal and interannual variation of inundation could be improved for low vegetated areas combining JERS with other sensors (Radarsat and ASAR for radar imagery or SPOT VGT, MODIS and MERIS for multispectral imagery).

Satellite radar altimetry has the ability to monitor variations in water level over wetlands, rivers and associated floodplains. It represents a unique source of data for floodplain, as the in-situ data records are generally located on the river mainstream. Although the radar altimetric measurements are still suffering severe limitations (Birkett, 1998; Birkett et al., 2002), the capability to sample, from one cycle to another, both mainstream and floodplain is a clear advantage compared with traditional in-situ measurements. This aspect is essential because it has been shown that the water volume stored in floodplains cannot be inferred from the flood extent, nor the elevation of the flood by its extent. On the contrary, it seems that significant geographical discrepancies exist in the way the flood extends with increasing water level. Better results of water cycle monitoring can be expected from a better sampling both in time and space. To achieve this goal, the combination of data from the present radar altimeters (T/P, ERS-1\&2, Jason-1, ENVISAT RA-2) can be useful. With the current altimeters, the difference in water level between the rivers and the associated floodplains is 
lower or equal to the dispersion of the measurements. The next generation of altimeters (Cryosat, Jason-2, the Water mission) is expected to provide a better accuracy. Thus, the choice of the geographical range reflects the nature of the selected target and a clear distinction between rivers and the associated floodplains can be achieved. 


\section{ACKNOWLEDGEMENTS}

This article was written within the framework of a collaboration between the GOHS team (Géodésie, Océanographie et Hydrologie Spatiale) at LEGOS (Laboratoire d 'Etudes en Géophysique et Océanographie Spatiales) and LMTG (Laboratoire des Mécanismes de Transfert en Géologie). The authors would like to acknowledge the CTO (Centre de Topographie des Océans) at LEGOS for the provision of the Topex/Poseidon GDR dataset and the HYBAM project for the in-situ gauge measurements. We are particularly grateful to thank Guy Lemichel for reviewing the English version of the paper. We express our gratitude to an anonymous reviewer for his very helpful comments and corrections. One of the authors, F.F. was supported by a grant from CNES (Centre National d'Etudes Spatiales, France) and Alcatel Space. 


\section{REFERENCES}

Alsdorf D.E., Melack J.M., Dunne T., Mertes L.AK., Hess L. L., Smith L.C. (2000). Interferometric radar measurements of water level changes on the Amazon floodplain, Nature, 404, 174-177.

Alsdorf D.E., Smith L.C., Melack J.M. (2001). Amazon floodplain water level changes measured with interferometric SIR-C radar, IEEE Trans. Geosci. Remote Sensing, 39 (2), $423-431$.

Alsdorf D.E. (2003). Water storage of the central Amazon floodplain measured with GIS and remote sensing imagery, Annals of the Association of American Geographers, 93 (1), 55-66. AVISO (1996). AVISO User Handbook: Merged TOPEX/POSEIDON Products, AVI-NT-02101-CN, 3-rd ed, CNES, Toulouse, France, 194 pp.

Bates P.H. (2000). A simple raster-based model for flood inundation simulation, J. Hydrol., $236,54-77$.

Birkett C.M. (1998). Contribution of the TOPEX NASA radar altimeter to the global monitoring of large rivers and wetlands, Water Resour. Res., 34 (5), 1223-1239.

Birkett C.M., Mertes L.A.K., Dunne T., Costa M.H., Jasinski M.J. (2002). Surface water dynamics in the Amazon Basin : Application of satellite radar altimetry, J. Geophys. Res., 107 (D20), 8059-8080.

Chapman B., Siqueira P., Freeman A. (2002). The JERS Amazon Multi-season Mapping Study (JAMMS): Observation strategies and data characteristics, Int. J. Remote Sensing, 23 (7), 1427-1446.

Coe M.T., Costa M.H., Botta A., Birkett C.M. (2002). Long term simulations of discharge and floods in the Amazon Basin, J. Geophys. Res., 107 (D20), 10,129-10,146. 
Frazier P., Page K., Louis J., Briggs S., Robertson A.I. (2003). Relating wetland inundation to river flow using Landsat TM data, Int. J. Remote Sensing, 24 (19), 3755-3770.

Fu L.L., Cazenave A. (2001). Satellite altimetry and Earth science, a handbook of techniques and applications, Academic Press, London, U.K.

Hamilton S.K., Sippel S.J., Melack J.M. (2002). Comparison of innundation patterns among major South American floodplains, J. Geophys. Res., 107 (D20), 10.129-10.143.

Hayashi M., van der Kamp G. (2000). Simple equations to represent the volume area depth relations of shallow wetlands in small topographic depressions, J. Hydrol., 237, 74-85.

Hess L.L., Melack J.M., Filoso S., Wang Y. (1995). Delineation of inundated area and vegetation along the Amazon floodplain with SIR-C synthetic aperture radar, IEEE Trans. Geosci. Remote Sensing, 33, 896-904.

Hess L.L., Melack J.M., Novo E.M.L.M., Barbosa C.C.F., Gastil M. (2003). Dual-season mapping of wetland inundation and vegetation for the central Amazon basin, Remote Sens. Environ., 87 (4), 404-428.

Junk W., Bayley P.B., Sparks R.E, 1989. The flood pulse concept in river floodplain systems, in D.P. Dodge (Ed.) Proceedings of the International Large River Symposium. Can. Spec. Pub. Fish. Aquat. Sci. 106, 110-127.

Liebmann B., Marengo J.A. (2001). Interannual variability of the rainy season and rainfall in the Brazilian Amazon basin, J. Clim., 14, 4308-4318.

Maheu C., Cazenave A., Mechoso C.R. (2003). Water level fluctuations in the Plata basin (South America) from Topex/Poseidon satellite altimetry, Geophys. Res. Let., 30 (3), $1143-$ 1146.

Marengo J.A., Liebmann B., Kousky V.E., Filizola, Wainer I.C. (2001). Onset and end of the rainy season in the Brazilian Amazon basin, J. Clim., 14, 833-852. 
Meade R.H., Rayol J.M., Conceicão S.C. da, Natividade J.R.G. (1991). Backwater effects in the Amazon river basin of Brazil, Environ. Geol. Water Sci., 18 (2), 105-114.

Mertes L.A.K., Daniel D.L., Melack J.M., Nelson B., Martinelli L.A., Forsberg B.R. (1995). Spatial patterns of hydrology, geomorphology, and vegetation on the floodplain of the Amazon River in Brazil from remote sensing perspective, Geomorphology, 13, 215-232.

Mertes L.A.K. (1997). Documentation and significance of the perirheic zone on inundated floodplains. Water Resour. Res., 33 ( 7), 1749-1762.

Oliveira Campos I. de, Mercier F., Maheu C., Cochonneau G., Kosuth P., Blitzkow D., Cazenave A. (2001). Temporal variations of river basin waters from Topex/Poseidon satellite altimetry; application to the Amazon basin, C.R. Acad. Sci. Paris, Sciences de la Terre et des planètes, 333, 1-11.

Priestnall G., Jaafar J., Duncan A. (2000). Extracting urban features from LIDAR-derived digital surface models. Computers, Environment and Urban Systems, 24, 65-78.

Rabus, B., Eineder M., Roth A., Bamler R. (2003). The shuttle radar topography mission- a new class of digital elevation models acquired by spaceborne radar, Photogramm. Eng. Rem. Sens., 57, 241-262.

Reigber C., Schmidt R., Flechtner F., König R., Meyer U., Neumayer K.H., Schwintzer P., Zhu S.Y. (2005). An Earth gravity field model complete to degree and order 150 from GRACE: EIGEN-GRACE02S, Journal of Geodynamics, 39 (1), 1-10.

Richards J. A., Sun G.Q., Simonetti D.S. (1987). L-band radar backscatter modeling of forest stands, IEEE Trans. Geosci. Remote Sensing, 25, 487-498.

Richey J.E., Nobre C., Deser C. (1989). Amazon river discharge and climate variability : 1903 to 1985 , Science, $246,101-102$. 
Richey J.E., Melack J.M., Aufdenkampfe A.K., Ballester V.M., Hess L.L. (2002). Outgassing from Amazonian rivers and wetlands as a large tropical source of atmospheric $\mathrm{CO} 2$, Nature, 617, doi:10.1038/416617a.

Rosenqvist A., Shimada M., Chapman B., Freeman A., Grandi G. de, Saatchi S., Raustet Y. (2000). The Global Rain Forest Mapping project - a review, Int. J. Remote Sensing, 21 (6 \&7), $1375-1387$.

Saatchi S. S., Nelson B., Podest E., Holt J. (2000). Mapping Land-cover types in the Amazon Basin using 1 km J-ERS-1 mosaic, Int. J. Remote Sensing, 21 (6\&7), 1201-1234.

Siqueira P., Chapman B., McGarragh, G. (2003). The coregistration, calibration, and interpretation of multiseason JERS-1 SAR data over South America, Remote Sens. Env., 87, 389-403.

Sippel S.J., Hamilton S.K., Melack J.M., Novo E.M.M. (1998). Passive microwave observations of inundation area and the area/stage relation in the Amazon River floodplain, Int. J. Remote Sens., 19, 3055-3074.

Smith L.C., Isacks B.L., Forster R.R., Bloom A.L., Preuss I. (1995). Estimation of discharge from braided glacial rivers using ERS 1 synthetic aperture radar : first results, Water Resour. Res., 31 (5), 1325-1329.

Smith L.C., Isacks B.L., Bloom A.L., Murray A.B. (1996). Estimation of discharge from three braided rivers using synthetic aperture radar imagery: potential application to ungauged basins, Water Resour. Res., 32 (7), 2031-2034.

Smith L.C. (1997). Satellite remote sensing of river innundation area, stage and discharge: a review, Hydrol. Process., 11, 1427-1439.

Sternberg H. (1975). The Amazon River of Brazil, Geographische Zeitschrif, 1-74.

Townshend P.A., Walsh S.J. (1998). Modelling floodplain inundation using an integrated GIS with radar and optical remote sensing, Geomorphology, 21, 295-312. 
Townsend P.A., Foster J.R. (2002). A synthetic aperture radar - based model to assess historical changes in lowland hydroperiod, Water Resour. Res., 38 (7), W1115, doi:10.129/2001WR001046.

Töyrä J., Pietroniro A., Martz L.W. (2001). Multisensor hydrologic assessment of a freshwater wetland, Remote Sens. Environ., 75, 162-173.

Usachev V.F. (1983). Evaluation of flood plain inundations by remote sensing methods, Proceedings of the Hamburg Symposium, IAHS pub., 145, 475-482.

Wang Y., Hess L.L., Filoso S., Melack J.M. (1995). Understanding the radar backscattering from flooded and non-flooded Amazonian forests: Results from canopy backscatter modelling, Remote Sens. Environ., 54, 324-332. 


\section{TABLE CAPTION}

Table 1: Total areas of each class in the Negro river basin, based on JERS-1 SAR mosaics from two dates.

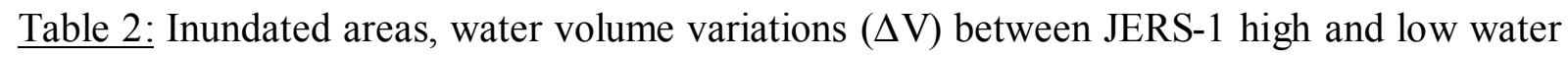
stages, and half peak flow integrated discharge for each sub-basin of Negro River basin.

Table 3: Percentage of area inundated with reference to total area for each sub-basin of the Negro.

Table 4: Standard deviations (minimum, mean and maximum). Mean differences between minimum water level for 1992-2002 (Mean 1), minimum for 1995 (Mean 2) and T/P derived water levels for JERS low water. Mean differences between maximum water level for 19922002 (Mean 3), maximum water level for 1996 (Mean 4) and T/P derived water levels for JERS high water.

Table 5: Differences between water levels at the dates of the JERS mosaic (1995 for low water stage or 1996 for high water stage) and minimum for 1995, maximum 1996 for each T/P altimetric station over river channels. 


\section{FIGURE CAPTIONS}

Figure 1: The Negro River sub-basin from JERS-1 radar mosaic. The thick white line represents the boundary of the Negro River. Each thin white line accounts for a Topex/Poseidon track. Black dots in a white circle represent in-situ gauge stations, black dots in a white square, altimetric stations over the Negro River sub-basin.

Figure 2: Classification results for the Negro River basin on JERS-1 radar images.

Figure 3: Extent of inundation as estimated from JERS-1 low water acquisition (red) and high water acquisition (black).

Figure 4: Examples of time series of water level : (a) for single channel rivers, (b) for a double channel river, (c) over flooded areas. The thin white line on the left part of (a) represents the water level variations at Manaus in-situ gauge station.

Figure 5: Water level (m wrt GRACE geoid) map for JERS-1 low water acquisition.

Figure 6: Water level (m wrt GRACE geoid) map for JERS-1 high water acquisition.

Figure 7: Map of water level difference (m) between JERS-1 low and high water acquisition.

Figure 8: Profiles of the Negro River main stream (a), Uaupes River (b) and Branco River (c).

Figure 9: Water volume variation in the Negro River sub-basin. 
Figure 1:

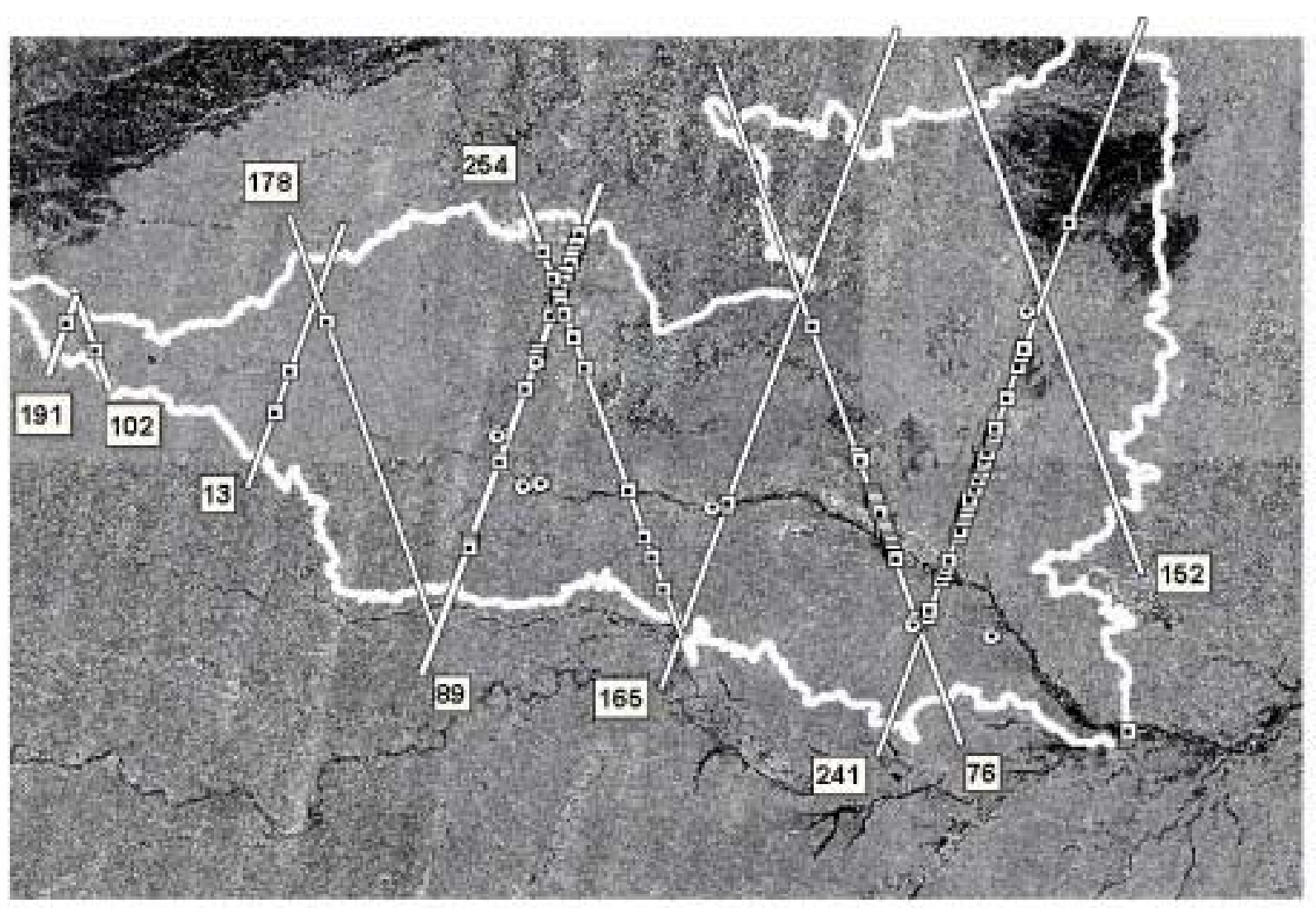


Figure 2:

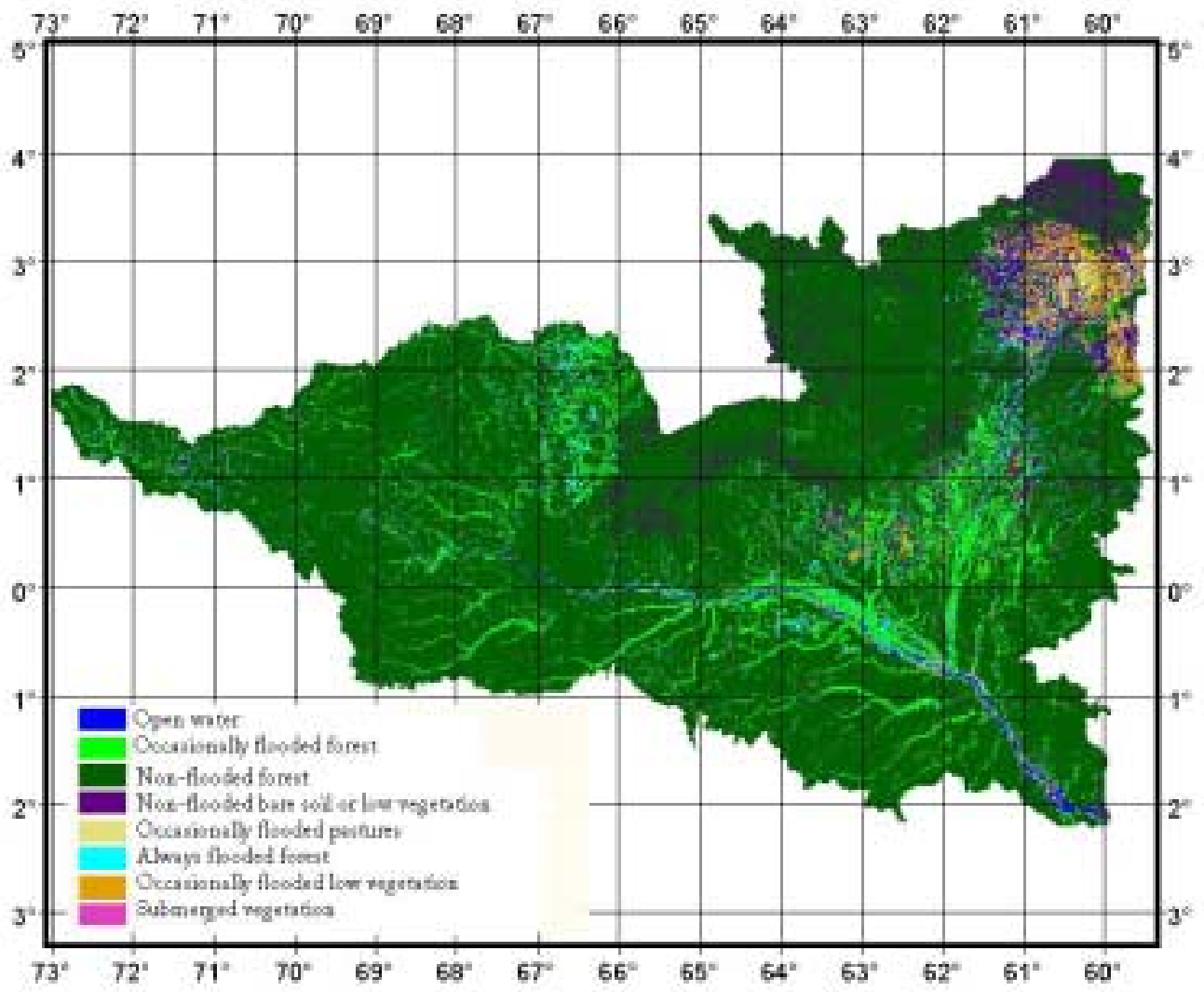


Figure 3 :

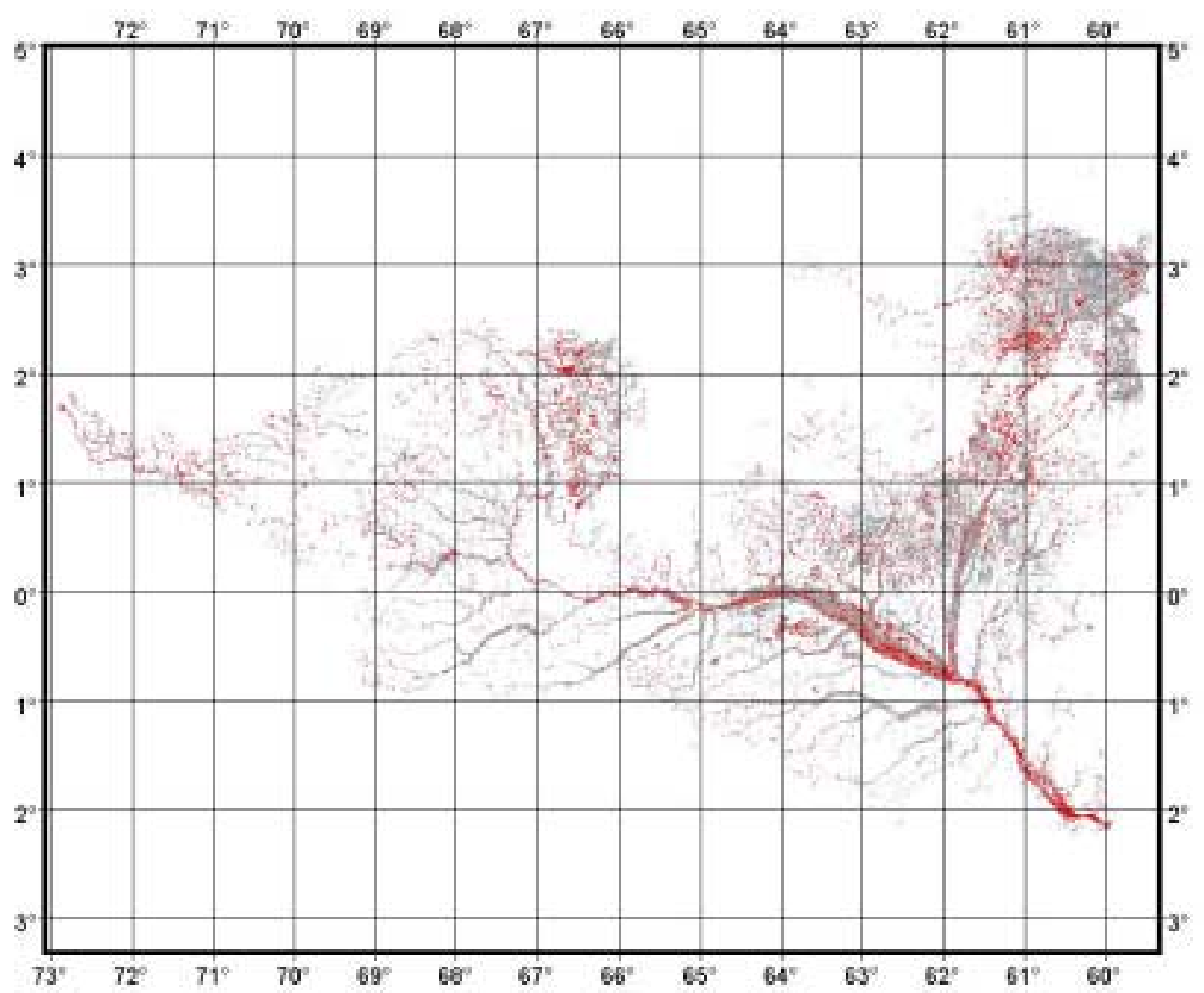


Figure 4:

(a)
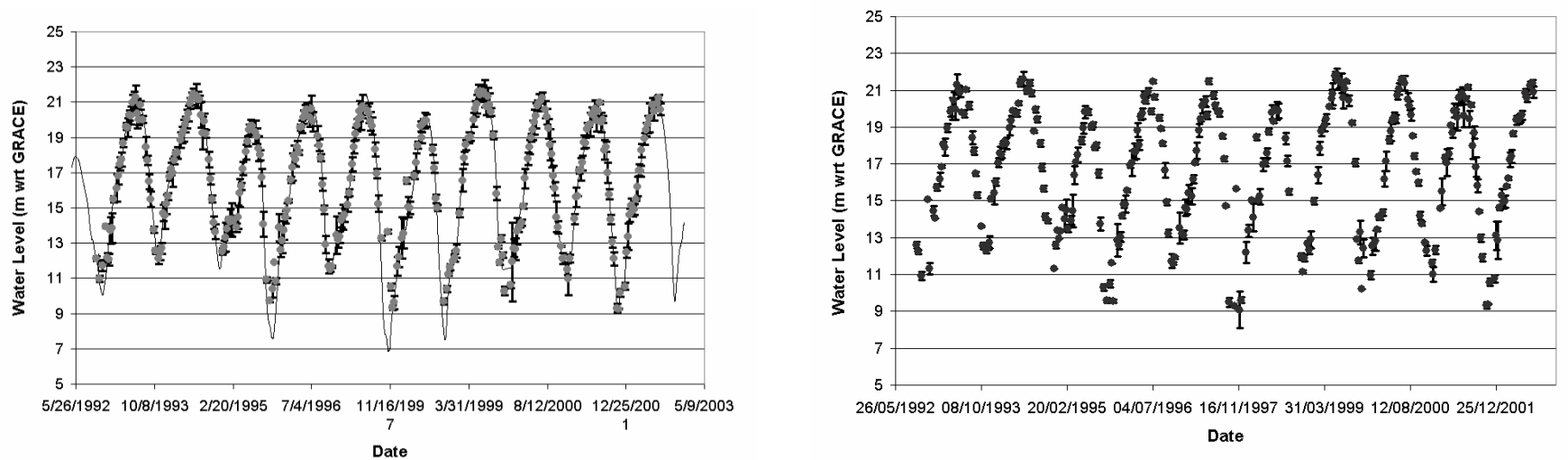

(b)
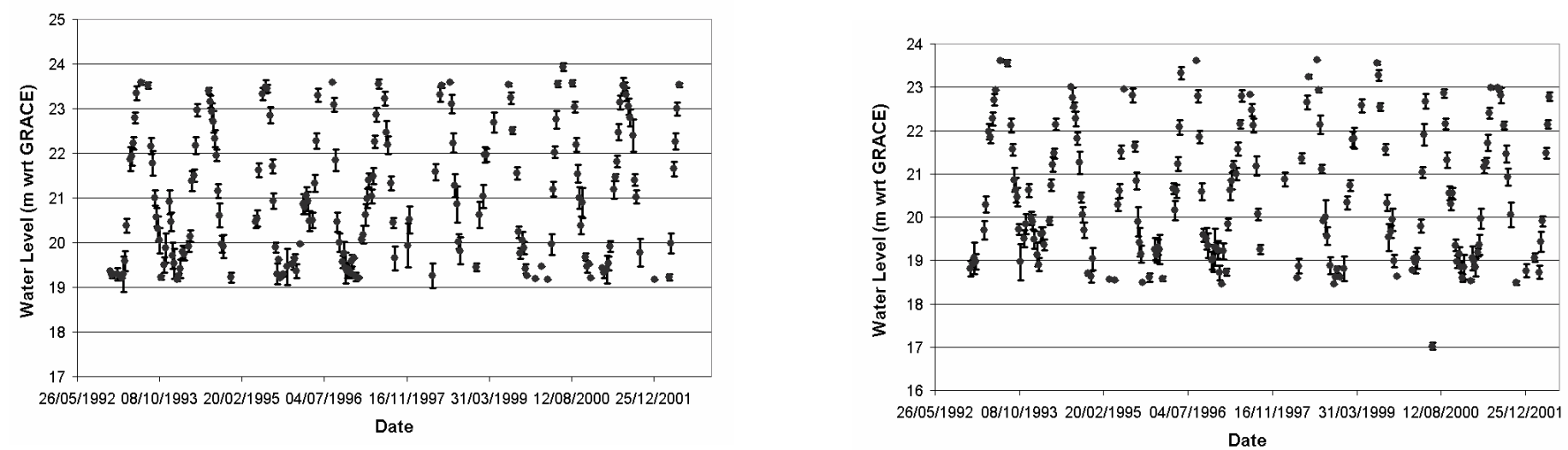

(c)
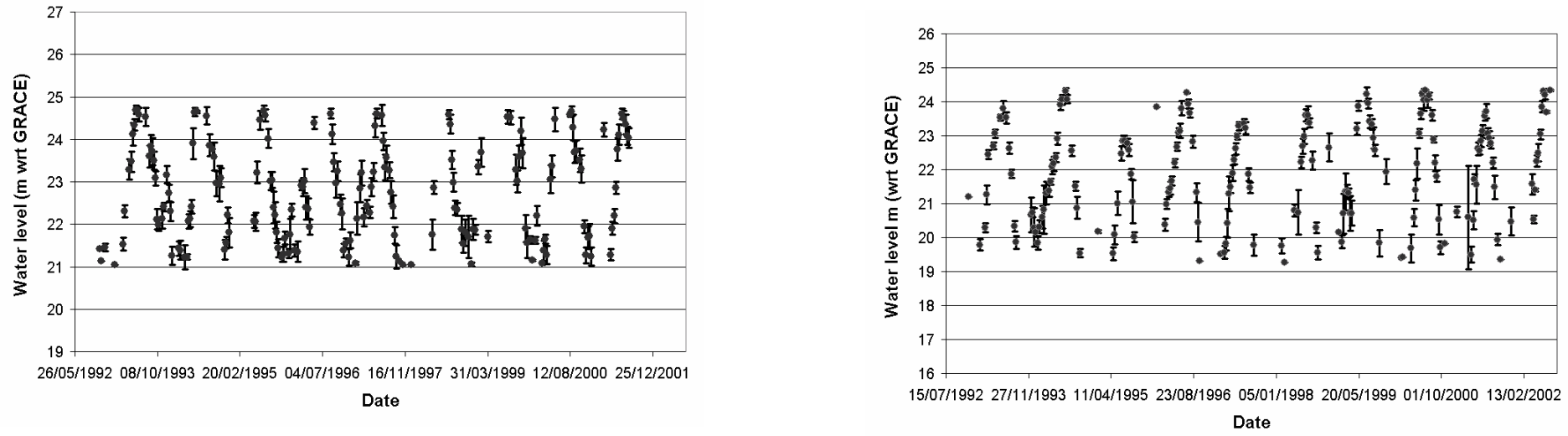
Figure 5:

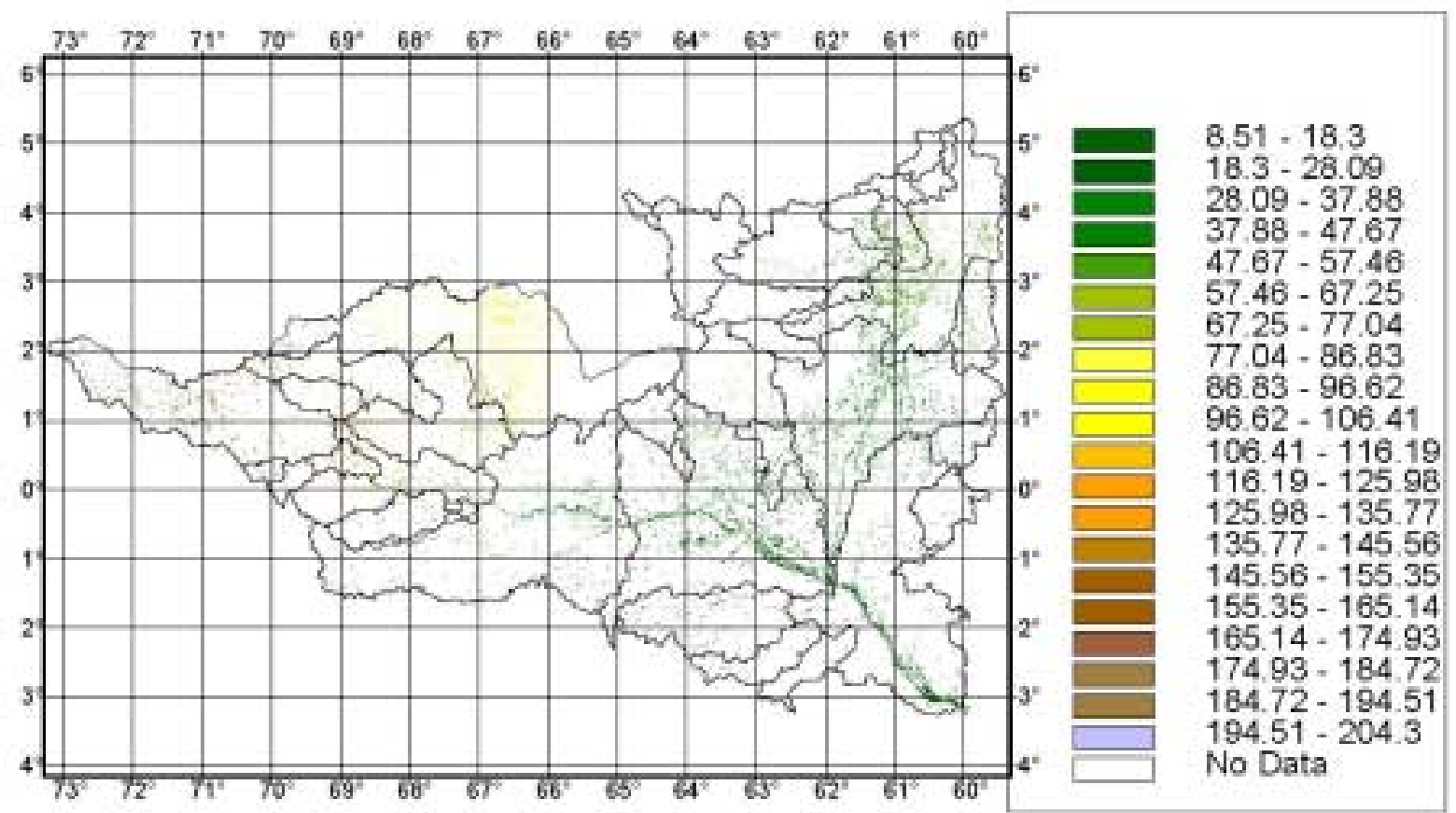


Figure 6:

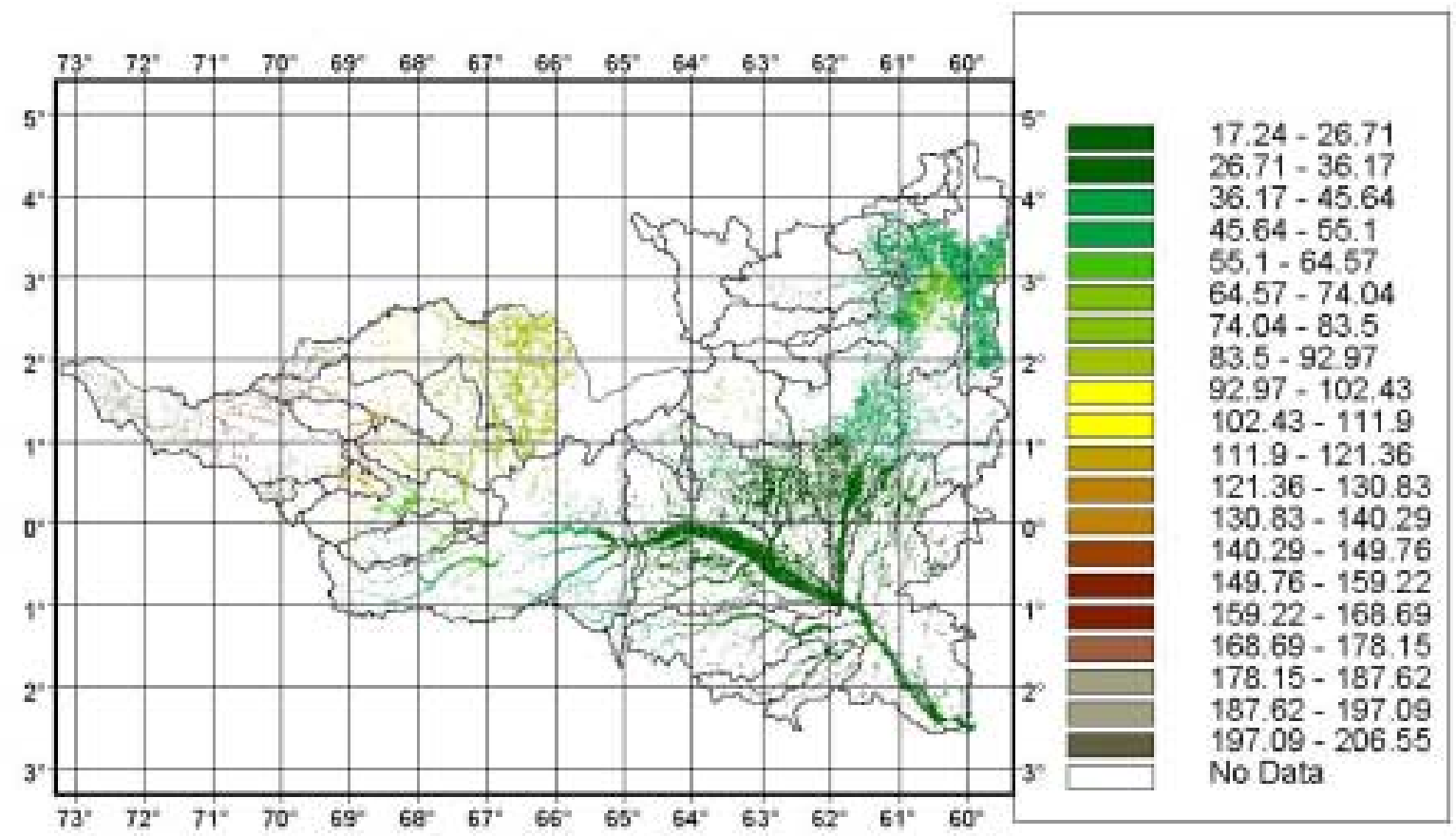


Figure 7 :

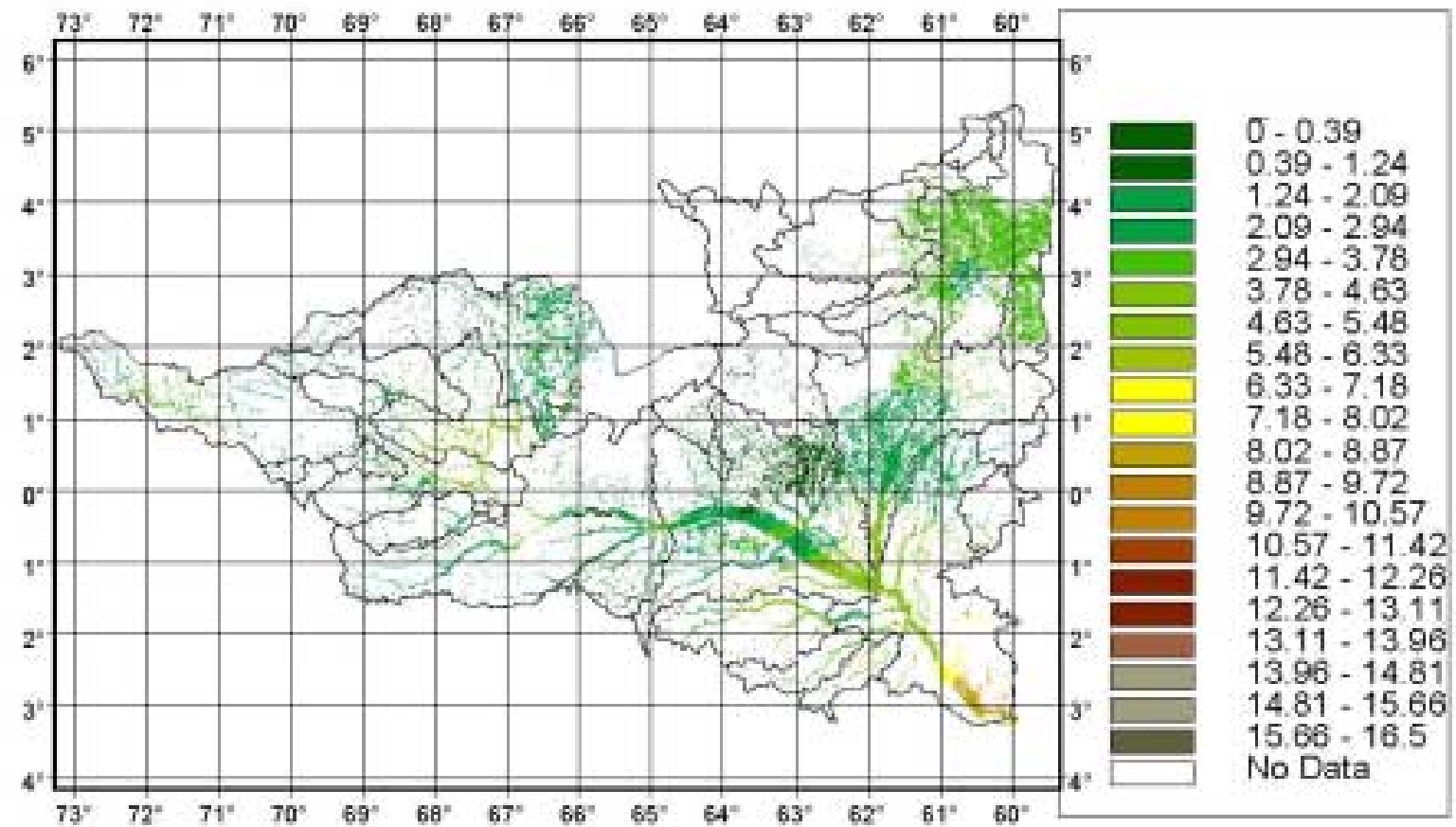


Figure 8 :

(a)

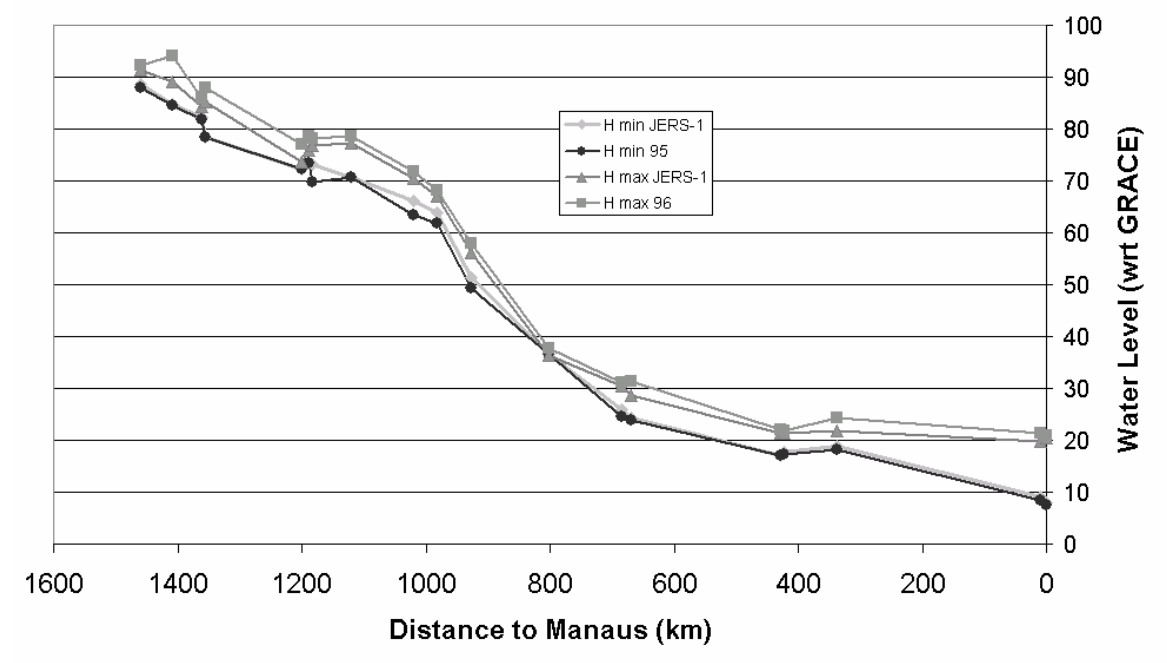

(b)

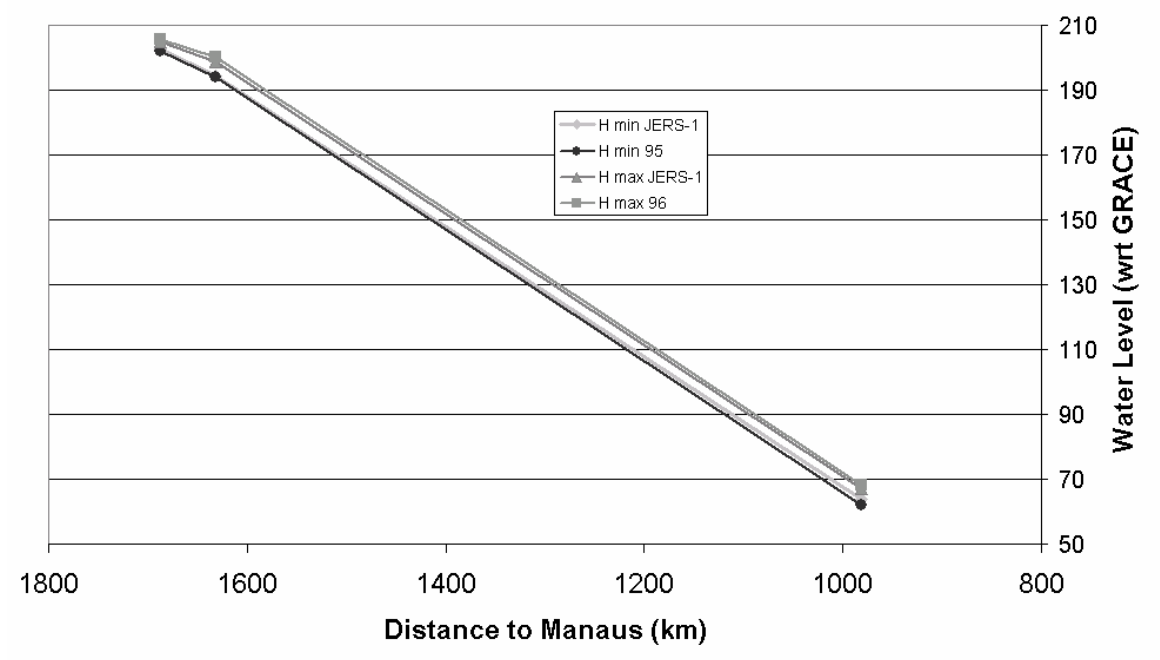

(c)

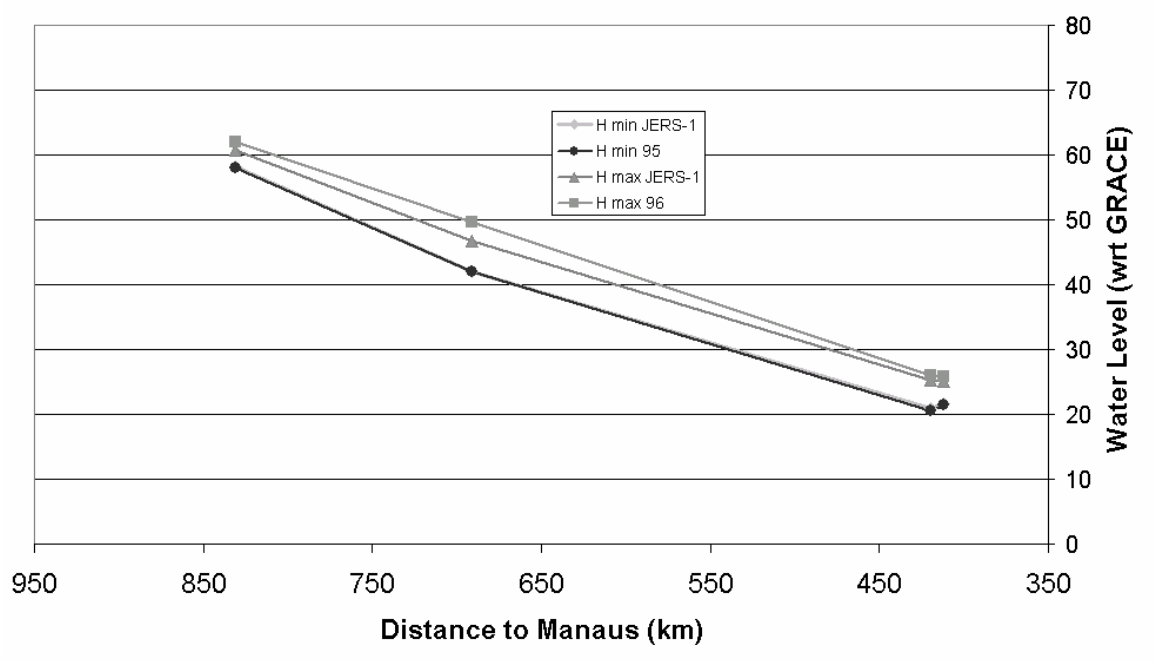


Figure 9:

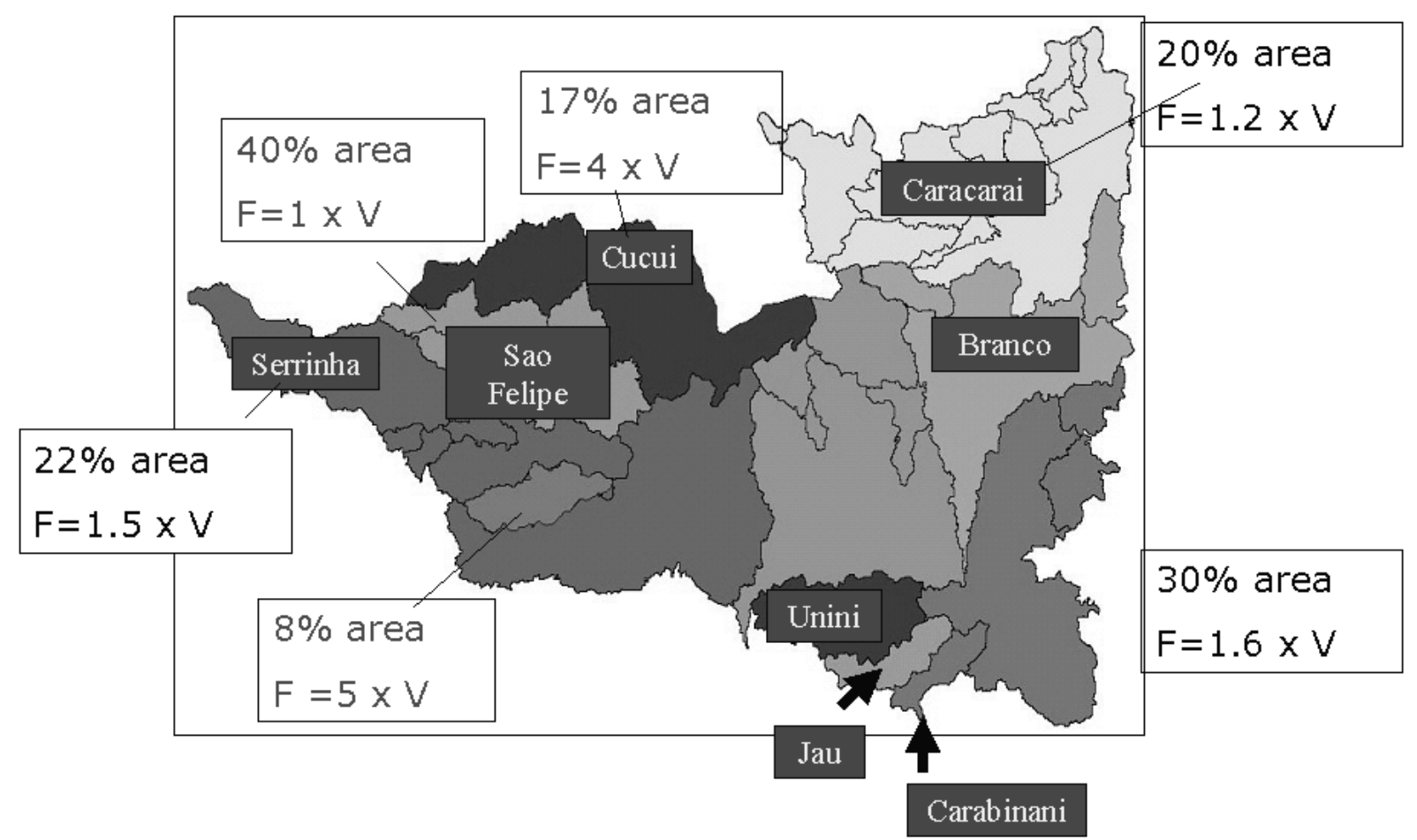


$\underline{\text { Table } 1}$

\begin{tabular}{|c|l|r|}
\hline $\begin{array}{c}\text { Class } \\
\text { number }\end{array}$ & Type of vegetation and flood & Area $\mathbf{( k m}^{2} \mathbf{)}$ \\
\hline 1 & Open waters & 14,100 \\
\hline 2 & Occasionally flooded forest & 79,700 \\
\hline 3 & Non-flooded forest & 510,650 \\
\hline 4 & $\begin{array}{l}\text { Non-flooded bare soil or low } \\
\text { vegetation }\end{array}$ & 42,140 \\
\hline 5 & Occasionally flooded pastures & 7,560 \\
\hline 6 & Always flooded forest & 21,860 \\
\hline 7 & $\begin{array}{l}\text { Occasionally flooded low } \\
\text { vegetation }\end{array}$ & 29,530 \\
\hline 8 & $\begin{array}{l}\text { Submerged vegetation during } \\
\text { high water }\end{array}$ \\
\hline
\end{tabular}


Table 2:

\begin{tabular}{|c|c|c|c|c|c|c|}
\hline Watershed & $\begin{array}{l}\text { Total area } \\
\left(\mathrm{km}^{2}\right)\end{array}$ & $\begin{array}{l}\text { Inund. } \\
\left(\mathrm{km}^{2}\right)\end{array}$ & $\begin{array}{l}\text { Inund./Total } \\
(\%)\end{array}$ & $\Delta \mathrm{V}\left(\mathrm{km}^{3}\right)$ & $\begin{array}{l}1 / 2 \text { peak flow } \\
\left(\mathrm{km}^{3}\right)\end{array}$ & $\begin{array}{l}1 / 2 \\
\mathrm{PF} / \Delta \mathrm{V}\end{array}$ \\
\hline $\mathrm{Jau}$ & 9,040 & 665 & 7.4 & 1.8 & & \\
\hline Curicuriari & 12,600 & 1,010 & 8.0 & 2.0 & 9.4 & 4.7 \\
\hline Carabinani & 6,970 & 620 & 8.9 & 1.8 & & \\
\hline Unini & 23,770 & 2,480 & 10.4 & 6.0 & & \\
\hline \begin{tabular}{|l|} 
Negro \\
downstream
\end{tabular} & 77,530 & 9,920 & 12.8 & 38.8 & & \\
\hline Cucui & 70,740 & 12,140 & 17.1 & 16.2 & 64.7 & 4.0 \\
\hline Caracarai & 120,350 & 23,580 & 19.6 & 42.2 & 51.6 & 1.2 \\
\hline Serrinha & 157,950 & 35,220 & 22.3 & 57.0 & 84.0 & 1.5 \\
\hline FozBranco & 109,350 & 28,150 & 25.7 & 51.8 & & \\
\hline Sao Felipe & 48,350 & 17,740 & 36.7 & 26.7 & 29.4 & 1.1 \\
\hline Branco & 75,510 & 47,430 & 62.8 & 86.8 & & \\
\hline Downstream & 302,170 & 89,270 & 29.5 & 187.0 & 302.5 & 1.6 \\
\hline
\end{tabular}


Table 3:

\begin{tabular}{|l|r|r|r|r|r|r|r|r|r|}
\cline { 2 - 11 } \multicolumn{1}{c|}{} & \multicolumn{10}{|c|}{ Inundated area (\%) } \\
\hline Sub-basin & $\begin{array}{l}\text { class } \\
1\end{array}$ & class 2 & class 5 & class 6 & class 7 & class 8 & $\begin{array}{l}\text { Low } \\
\text { stage }\end{array}$ & $\begin{array}{l}\text { High } \\
\text { stage }\end{array}$ & $\begin{array}{l}\text { High stage } \\
\text { wrt Negro } \\
\text { Basin }\end{array}$ \\
\hline Jau & 0.02 & 12.90 & 0.00 & 0.60 & 0.00 & 0.20 & 0.62 & 14.33 & 6.29 \\
\hline Curicuriari & 5.09 & 8.12 & 0.01 & 0.99 & 0.04 & 0.27 & 6.08 & 14.51 & 6.37 \\
\hline Carabinani & 16.07 & 4.61 & 0.14 & 0.19 & 0.01 & 0.02 & 16.26 & 21.03 & 9.23 \\
\hline Unini & 0.11 & 10.43 & 0.02 & 1.58 & 0.05 & 0.52 & 1.69 & 12.70 & 5.57 \\
\hline $\begin{array}{l}\text { Negro } \\
\text { downstream }\end{array}$ & 3.53 & 7.97 & 0.79 & 1.73 & 0.42 & 0.54 & 5.26 & 14.97 & 6.57 \\
\hline Cucui & 0.39 & 11.18 & 0.00 & 4.12 & 0.07 & 1.11 & 4.50 & 16.87 & 7.40 \\
\hline Caracarai & 2.07 & 2.10 & 4.59 & 2.18 & 15.31 & 0.40 & 4.25 & 26.65 & 11.69 \\
\hline Serrinha & 1.19 & 6.43 & 0.14 & 2.38 & 0.09 & 0.72 & 3.57 & 10.95 & 4.80 \\
\hline Foz Branco & 0.41 & 14.24 & 0.31 & 3.57 & 8.32 & 1.37 & 3.98 & 28.21 & 12.37 \\
\hline Sao Felipe & 1.22 & 8.96 & 0.10 & 3.25 & 0.06 & 0.75 & 4.47 & 14.33 & 6.29 \\
\hline Branco & 5.19 & 36.92 & 1.06 & 6.82 & 1.88 & 2.35 & 12.01 & 54.23 & 23.79 \\
\hline
\end{tabular}


Table 4:

\begin{tabular}{|l|l|l|l|l|l|l|l|}
\cline { 2 - 8 } \multicolumn{1}{c|}{} & $\begin{array}{l}\text { Mean std } \\
(\mathrm{m})\end{array}$ & $\begin{array}{l}\text { Max std } \\
(\mathrm{m})\end{array}$ & $\begin{array}{l}\text { Min std } \\
(\mathrm{m})\end{array}$ & $\begin{array}{l}\text { Mean 1 } \\
(\mathrm{m})\end{array}$ & $\begin{array}{l}\text { Mean 2 } \\
(\mathrm{m})\end{array}$ & $\begin{array}{l}\text { Mean 3 } \\
(\mathrm{m})\end{array}$ & $\begin{array}{l}\text { Mean 4 } \\
(\mathrm{m})\end{array}$ \\
\hline River & 0.22 & 0.40 & 0.10 & 0.98 & 0.40 & 1.95 & 1.55 \\
\hline Inundated area & 0.25 & 0.56 & 0.14 & 0.82 & 0.42 & 1.83 & 1.37 \\
\hline
\end{tabular}


$\underline{\text { Table 5: }}$

\begin{tabular}{|c|c|c|c|c|c|}
\hline River & Track & $\begin{array}{l}\text { Diff. } 1995 \\
\text { (m) }\end{array}$ & $\begin{array}{l}\text { Diff. } 1996 \\
\text { (m) }\end{array}$ & $\begin{array}{l}\text { Mean } 1995 \\
\text { (m) }\end{array}$ & $\begin{array}{l}\text { Mean } 1996 \\
\text { (m) }\end{array}$ \\
\hline Uaupes & $\mathrm{T} / \mathrm{P} 191$ & -0.70 & 0.71 & \multirow[t]{3}{*}{-1.03} & \multirow[t]{3}{*}{1.01} \\
\hline Uaupes & $\mathrm{T} / \mathrm{P} 102$ & -0.44 & 1.29 & & \\
\hline Uaupes/Negro & T/P 89 & -1.95 & 1.04 & & \\
\hline Negro & T/P 89 & -0.75 & 1.04 & \multirow[t]{14}{*}{-0.40} & \multirow[t]{14}{*}{2.06} \\
\hline Negro & T/P 89 & -0.05 & 5.08 & & \\
\hline Negro & T/P 254 & -0.43 & 1.70 & & \\
\hline Negro & T/P 89 & -0.01 & 2.89 & & \\
\hline Negro & T/P 89 & -0.09 & 3.50 & & \\
\hline Negro & T/P 89 & 0.00 & 2.82 & & \\
\hline Negro & T/P 89 & -0.05 & 1.24 & & \\
\hline Negro/Uaupes & T/P 89 & -1.95 & 1.04 & & \\
\hline Negro & $\mathrm{T} / \mathrm{P} 254$ & 0.00 & 1.30 & & \\
\hline Negro & $\mathrm{T} / \mathrm{P} 165$ & -0.39 & 2.78 & & \\
\hline Negro & T/P 76 & -0.06 & 0.70 & & \\
\hline Negro & $\mathrm{T} / \mathrm{P} 76$ & -0.31 & 0.48 & & \\
\hline Negro & $\mathrm{T} / \mathrm{P} 241$ & -0.72 & 2.57 & & \\
\hline Negro & $\mathrm{T} / \mathrm{P} 63$ & -0.81 & 1.69 & & \\
\hline Branco & $\mathrm{T} / \mathrm{P} 241$ & -0.26 & 1.21 & \multirow[t]{3}{*}{-0.23} & \multirow[t]{3}{*}{0.91} \\
\hline Branco & $\mathrm{T} / \mathrm{P} 241$ & -0.35 & 0.73 & & \\
\hline Branco & $\mathrm{T} / \mathrm{P} 241$ & -0.08 & 0.78 & & \\
\hline
\end{tabular}


$\underline{\text { Response to the reviewers : }}$

\section{Summary:}

According to your suggestions and comments, we have tried to make appropriate changes. Syntax, spelling and grammatical errors have been corrected thanks to the suggestions of Reviewer 3 and an English teacher from Toulouse University of Science, Guy Lemichel. We have further discussed the linear interpolation method which seems to be the most critical aspect of our work, explaining the reason of this choice. The previous studies part was completed using the different references you suggest. We have modified the part dealing with classification to show the differences between the classifier developed by our co-author JeanMichel Martinez and the methods presented by Saatchi et al. (2000), Hess et al. (2003), Siqueira et al. (2003). The conclusion was rewritten to summarize our work. The figures and tables (and their caption) were changed too.

\section{Reviewer 1 :}

We have corrected syntax, grammar errors to improve the quality of the manuscript thanks to the very helpful recommendations of Reviewer 3.

1: We explained and clarified the notions of water storage variation and water volume calculated from half peak flow integrated discharge in the additional paragraph 3.5.

2: Many studies such as Birkett et al. (2002) or Oliveira Campos et al. (2003) showed the quality of water level derived from radar altimetry measurements. We added in figure $4 \mathrm{a}$ comparison of the in-situ water levels at Manaus gauge station and the altimeter derived water level obtained $8.5 \mathrm{~km}$ upstream.

3: We have further discussed the interpolation method in paragraph 3.3. We explained the reason why we have choosed a linear interpolation scheme more than another model. In some cases (North/South flowing river parts), the interpolation method assumes that the water level in the river and in the floodplain can be linearly averaged. Alsdorf (2003) has pointed drops between the Amazon mainstream and the floodplain from 7 to $11 \mathrm{~cm}$ for distances of $30 \mathrm{~km}$. These water level differences are falling within the error range on altimetric measurements (table 4, and see also Birkett et al., 2002). Although not representing the short-term hydraulic processes linking the river and its floodplain (the measurements reported by Alsdorf (2003) were interferometric, on a 24 hours time period), we believe that the seasonal water level difference reaching 10 to $15 \mathrm{~m}$ at the mouth of the Negro, and of 1 to 2 meters upstream, can be therefore retrieved by our spatial approximation.

4 : The figures 1 and 6 have been merged into figure 1 to avoid redundance. The figures 3 and 4 have been color-merged into figure 3. Figure 12 was suppressed.

5: The important study from Birkett et al. (2002) on the use of radar altimetry for the monitoring of land waters is now referenced at different times in the new version of the manuscript (introduction, 2 times in 3.3 Water level maps for high and low stages, conclusion). We have completed the previous studies part thanks to your reading suggestions. 6: We rewrote the conclusion to summarize our work. We present first our results about water volume variation. Then, we discuss the use of imagery to delineate flood extent and what can be done with the present generation of sensors. The last concerns the use of altimetry to sample both rivers and associated and the necessity to combine data from different radar altimeters to improve the spatial and temporal sampling. 


\section{Reviewer 2:}

1 : We have corrected the numerous syntax, spelling and grammar errors following the very helpful suggestions of Reviewer 3.

2: After discussion with our co-author Jean-Michel Martinez, the presentation of the classification has been widely modified. A more complete review of the previous works is presented (Saatchi et al., 2000; Hess et al., 2003; Siqueira et al., 2003). We have corrected the mistake about the reference from Hess et al. (2004) in Hess et al. (2003).

3: see Reviewer 1; point 3.

4: The part 3.1.2 "Classification method for flood extent" which now presents the classification method over the entire Amazon basin has been widely modified. Previous works 5: The earlier and extensive study from Birkett et al. (2002) is a very important work about the use of radar altimetry for land waters. It was referenced at different times in this new version of the manuscript (introduction, 2 times in 3.3 Water level maps for high and low stages, conclusion).

6: see Reviewer 1; point 3. We reduced the number of significant digits in tables 1 and 2.

7: The error analysis was modified. The error sources include mis-classifications, T/P altimetry measurements and the planar fit.

8: We added the reference to Meade et al. (1991) for the backwater condition.

9: See Reviewer 1; point 1.

10: We have suppressed this part.

\section{Reviewer 3:}

We are very grateful for all the syntax, spelling and grammatical corrections you propose. They allow us to present a more understandable manuscript to the reviewers. They were incorporated in the corrected version. We have also changed the title of the paper following your suggestion.

1: After discussion with our co-author Jean-Michel Martinez, we have widely modified the part 3.1.2 "Classification method for flood extent" which presents his classification method over the entire Amazon basin. The method used is, we hope, clearly described, with many details, to allow the readers to assess the classifier before the publication of Martinez works. The results of the classification, however, have to be seen as intermediary (but important) results, and not as the major part of the work presented here.

2: We have tried to clearly separate methods and results. The classification of the Negro river sub-basin, the flood extent maps, the water level maps now appear in the results part.

3: The tables and figures legends are more detailed to make them more understandable.

4: We have enlarged the figures as soon as possible to improve their legibility. 